\title{
IMPLEMENTATION OF LEARNING HISTORY BASED ON LESSON STUDY
}

\author{
Kuswono \\ Pendidikan Sejarah FKIP Universitas Muhammadiyah Metro \\ Email: kuswono@ummetro.ac.id
}

\begin{abstract}
Abstrak
Tujuan dari penelitian ini adalah untuk mendeskripsikan penerapan pembelajaran sejarah berbasis Lesson Study. Metode penelitian ini adalah deskriptif kualitatif dengan teknik pengumpulan data yaitu wawancara, observasi, kuesioner dan pengumpulan dokumen. Hasilnya menunjukkan bahwa guru masih memperlakukan hal yang sama antara siswa yang memiliki kemampuan berbeda dalam bidang sejarah. Model master kesulitan dalam integrasi nilai karakter salah satu penyebabnya adalah tidak adanya bahan ajar yang secara eksplisit menyajikan nilai material historis yang terintegrasi. Masih ada salah persepsi dalam pelaksanaan Lesson Study ini dibuktikan dengan aktivitas pengamat yang berkomunikasi dengan siswa saat pelaksanaan pembelajaran berlangsung.
\end{abstract}

Kata kunci: pembelajaran, sejarah, Lesson Study

\section{Abstract}

The purpose of this study is to describe the implementation of Lesson Study-based history learning. This research method is qualitative descriptive with data collecting technique that is interview, observation, questionnaire and document collection. The results showed that the teacher still treats the same between students who have different abilities in the field of history. Master model difficulty in the integration of character values one of the causes is the absence of teaching materials that explicitly presents the historical material integrated character values. There is still a misperception in the implementation of Lesson Study is evidenced by observer activities that communicate with students when the implementation of learning takes place.

Keywords: learning, history, Lesson Study

\section{PENDAHULUAN}

Lesson Study sebagai salah satu model peningkatan kualitas pembelajaran mendapat sambutan yang luar biasa dikalangan akademisi dan praktisi khususnya di Indonesia. Lesson Study menjadi bagian penting dalam implementasi pendidikan di Jepang yang kemudian merambah ke berbagai negara. Lesson Study menjadi solusi peningkatan kualitas pembelajaran, pada pelajaran yang dianggap sulit dibeberapa negara yang menerapkannya.

\section{The Third International} Mathematics and Science Study (TIMSS) menjadi latar belakang tereksposnya Lesson Study di beberapa negara. Berawal dari rendahnya skor rata-rata matemtika di Amerika Serikat dibandingkan dengan negara-negara lainnya dalam TIMSS. Kemudian ditindaklanjuti dengan studi banding mengenai pembelajaran matematika di Jepang dan Jerman. Bahkan pemerhati pendidikan di Amerika Serikat menyadari bahwa Amerika Serikat belum memiliki sistem untuk melakukan peningkatan 
mutu pembelajaran, sedangkan Jepang dan Jerman melakukan peningkatan mutu secara berkelanjutan. Oleh karena itu, para ahli pendidikan Amerika Serikat mengadopsi Lesson Study dari Jepang dan kemudian mengembangkannya di negara-negara lain. Di Jepang sendiri Lesson Study dikenal dengan Jogyokenkyuu yang telah berjalan lama. Abad ke-19 (1870-an). Lesson Study telah dimulai di Jepang. Sementara di Indonesia Lesson Study baru diadopsi tahun 1998. Pertama kali dikenalkan pada tiga universitas eks-IKIP yaitu (Universitas Negeri Malang, Universitas Negari Yogyakarta, dan Universitas Pendidikan Indonesia).

Lesson Study (LS) is a highly specified form of classroom action research focusing on the development of teacher practice knowledge. It has been in use in Japan since the 1870s. LS therefore pre-dates action research as we know it in the West, by some 70 years (Dudley, 2014).

Lesson Study sebagai suatu model pembinaan profesi pendidik melalui pengkajian pembelajaran secara kolaboratif dan berkelanjutan, berlandaskan prinsip-prinsip kesejawatan untuk membangun masyarakat belajar (Susilo, H., 2013). Lesson Study adalah proses pengembangan profesional untuk guru dimana mereka berkolaborasi dan meneliti cara-cara efektif dalam konsep pembelajaran dan mengajarkannya
(Baum, E., Brown, K., Minter, B., \& Smoak, T., 2015).

Penelitian mengenai Lesson Study telah banyak dilakukan selain meningkatkan kualitas guru, Lesson Study adalah sebuah inovasi dama meningkatkan profesionalisme guru. Lesson Study memungkinkan seluruh komponen pendidikan belajar meningkatkan kapasitas sampai melintasi batas budaya. Lesson Study dapat mengajarkan kita tentang upaya untuk meningkatkan pengajaran, seperti penelitian pembelajaran, memeriksa dan memperbaiki kinerja guru dan sekaligus meningkatkan kualitas pembelajaran untuk siswa (Lewis, C., Perry, R., \& Murata, A., 2006).

Lesson Study dianggap efektif dalam memperbaiki praktik pembelajaran. Lesson Study fokus pada penyelesaian berbagai masalah pembelajaran, mengambil konteks pembelajaran dan pengalaman guru lain, dan memberikan dukungan kepada guru dalam hubungan sejawat. Dengan kata lain, Lesson Study memberikan banyak kesempatan kepada guru untuk membuat bermakna ide-ide pendidikan dalam praktik pembelajaran mereka, untuk mengubah perspektif mereka tentang pembelajaran, dan untuk belajar mengamati praktik pembelajaran mereka dari perspektif siswa (Mahmudi, A., 2009). 
Kekuatan atau keunggulan Lesson Study seperti yang diungkapkan oleh Lewis, (2000) adalah pengembangan profesional perorangan; belajar mengamati siswa; menyebarkan konten dan pendekatan baru; menghubungkan praktik guru dengan tujuan sekolah dan tujuan yang lebih luas; menciptakan permintaan untuk perbaikan kualitas; membentuk kebijakan nasional; dan menghormati peran sentral guru. Pembelajaran di Jepang sangat mendukung Lesson Study di Jepang telah memiliki kurikulum bersama; kolaborasi yang mapan; Keyakinan bahwa pengajaran dapat ditingkatkan melalui usaha kolektif; refleksi diri; stabilitas kebijakan pendidikan; waktu pengembangan instruksional difokuskan pada instruksi; dan fokus pada keseluruhan anak.

Senada dengan pendapat di atas bahwa Lesson Study dapat meningkatkan profesionalisme guru, meningkatkan proses dan hasil belajar siswa. Saran dari penelitian ini yaitu pelaksanaan Lesson Study perlu dikembangkan di sekolah untuk perbaikan kualitas pembelajaran oleh guru dalam rangka menjadi guru yang profesional (Winarsih, A., \& Mulyani, S., 2012). Namun terdapat beberapa kendala yang dihadapi ketika mengimplementasikan Lesson Study diantaranya adalah adanya persepsi yang keliru tentang Lesson Study, penyusunan jadwal, pen-danaan, setting kelas, dan pendokumentasian (Mahmudi, A., 2009).

Dapat dilihat bahwa permasalahan sebetulnya bukan pada Lesson Study melainkan pada sumber daya manusia yang belum memahami dan menguasi konsep Lesson Study. Upaya untuk menghindari adanya salah persepsi mengenai Lesson Study yakni pada tahap perencanaan perlu dilakukan penyamaan persepsi antar-anggota kelompok. Penyamaan persepsi ditekankan pada pemahaman bahwa Lesson Study lebih dimaksudkan untuk meningkatkan kualitas pembelajaran, dan bukan untuk menilai guru.

Disisi lain Pembelajaran sejarah saat ini menghadapi banyak persoalan. Persoalan itu mencakup lemahnya penggunaan teori, miskinnya imajinasi, acuan buku teks dan kurikulum yang state oriented, serta kecenderungan untuk tidak memperhatikan fenomena globalisasi berikut latar belakang historisnya. Didalam proses pembelajaran sejarah, masih banyak guru menggunakan pardigma konvensional, yaitu paradigma 'guru menjelaskan murid mendengarkan'. Metode pembelajaran sejarah semacam ini telah menjadikan pelajaran sejarah membosankan. la kemudian tidak memberikan sentuhan emosional karena siswa merasa tidak terlibat aktif di dalam proses pembelajarannya (Subakti, 2010). Belajar sejarah sejatinya menggiring 
siswa untuk mampu berpikir kritis dan mampu mengkaji setiap perubahan di lingkungannya, serta memiliki kesadaran akan perubahan dan nilai-nilai yang terkandung dalam setiap peristiwa sejarah. Sehingga siswa yang belajar sejarah tidak gagap mengenai peruubahan-perubahan yang begitu cepat dalam masyarakat global seperti saat ini.

Selain itu, pembelajaran sejarah memiliki peran dalam internalisasi nilainilai karakter pada diri siswa. Pelajaran Sejarah memiliki arti strategis dalam pembentukan watak dan peradaban bangsa yang bermartabat serta dalam pembentukan manusia Indonesia yang memiliki rasa kebangsaan dan cinta tanah air. Penguatan pelajaran sejarah sebagai pendidikan karakter dapat diterapkan mulai dari tujuan, pelaksanaan pembelajaran, materi, sumber dan media, sampai dengan penilaian (Hasan, S. H., 2012).

Permasalahan-permasalahan dalam pembelajaran sejarah tentu bukan hal yang aneh lagi untuk dikaji. Stigma siswa mengenai pelajaran sejarah yang dianggap tidak penting, sulit move on, membosankan dan pelajaran menghafal yang penuh dengan tahun masa lalu, serta penuh kebohongan. Begitu menyakitkan ketika seorang siswa dengan nada tinggi mengatakan bahwa sejarah itu “omong kosong”. Namun stigma siswa tersebut tidak seta merta disalahkan atau guru sejarah secara membabi buta membela diri. Tetapi butuh solusi atau jalan keluar untuk menuntaskan permasalahan mengenai stigma siswa tersebut.

Lesson Study sebagai model peningkatan kualitas pembelajaran dapat menjadi solusi untuk pembelajaran sejarah. Walaupun Lesson Study pertama kali diterapkan pada pelajaran matematika tidak berarti tidak cocok untuk pembalajaran pada ilmu-ilmu sosal dan humaniora termasuk pelajaran sejarah. Permasalahan pembelajaran sejarah dapat diatasi dengan Lesson Study seperti yang di yang diungkapkan oleh Winarsih, A., \& Mulyani, S. (2012) dalam penelitiannya bahwa Lesson Study menjadi bagian yang berpengaruh dalam meningkatkan proses, hasil pembelajaran dan profesionalisme guru.

Penelitian ini akan memotret mengenai pelaksanaan pembelajaran sejarah dengan menerapkan Lesson Study di SMAN 1 Metro. Peneliti melibatkan mahasiswa pendidikan sejarah semester 6 dalam melakukan kegiatan Lesson Study tersebut. Perlu diketahui bahwa mahasiswa pendidikan sejarah semester 6 telah dibekali mengenai Lesson Study bahkan telah mempraktekannya ketika micro teaching. Sehingga pengetahuannya mengenai prosedur dalam Lesson Study telah meraka pahami. Tugas mereka adalah membawa Lesson Study dalam 
setiap pembelajarannya ketika praktek pengajar di sekolah.

Tempat penelitian adalah SMA Negeri 1 Metro. Sebagian besar guru di sekolah ini telah mengenal Lesson Study. Adanya kemitraan antara SMA N 1 Metro dengan Fakultas Keguruan dan IImu Pendidikan Universitas Muhammadiyah Metro dan selalu dijadikan tempat untuk mahasiswa calon guru melakukan praktek mengajar memudahkan bagi peneliti untuk melakukan penelitain. Para guru telah banyak mengenal Lesson Study walaupun tidak semua melakukannya. Sehingga mera paham menganai konsepkonsep Lesson Study.

Fokus penelitian ini adalah pelaksanaan pembelajaran sejarah dengan mengunakan Lesson Study. Sehingga pelaksanaan perencanaan dan refleksi hanya sepintas saya dipaparkan dalam penelitian ini. Pembahasan akan menyajikan mengani iklim kelas, proses pembalajaran, persepsi siswa mengenai pembelajaran sejarah, dan temuantemuan selama proses pembelajaran sejarah berlangsung.

\section{METODE PENELITIAN}

Metode penelitian ini adalah kualitatif deskriptif dengan teknik pengumpulan data yakni wawancara, observasi dan pengumpulan dokumen. Wawancara dilakukan kepada guru dan siswa, observasi dilakukan dalam proses pembelajaran sejarah. Sedangkan dokumentasi berupa perangkat pembelajaran sejarah. Selain itu untuk mengetahui persepsi siswa mengenai proses pembelajaran sejarah yang dilakukan oleh guru model maka disusun angket dengan beberapa indikatornya. Indikator-indikator tersebut yakni membuka pembalajaran, penguasaan materi pembelajaran, pemahaman guru model terhadap karakteristik siswa, penerapan strategi dan metode dalam pembelajaran, sistem penilaian (evaluasi), dan penanaman Karakter. Angket yang digunakan adalah angket penilaian kinerja guru dan telah divalidasi dengan nilai lebih dari 0,30 (> 0,30 ), sedangkan reliabilitas sebesar 0,938 (Kuswono, 2015).

\section{PEMBAHASAN}

Sabtu 6 Mei 2017 dilakukan Plan (perencanaan) dengan membahas dua RPP (Recana pelaksanaan pembelajaran) dengan guru model yang sama. Pembelajaran sejarah akan dilaksanakan pada kelas $X$ dengan materi peradaban Yunani dan Romawi. Sedangkan rencana yang lainnya yakni kelas XI dengan materi peristiwa-peristiwa sekitar Proklamasi.

Perencanaan (Plan) dilaksanakan dengan melibatkan guru, mahasiswa pendidikan sejarah dan dosen Sejarah. Pembahasan RPP disepakati bahwa metode diskusi terbimbing yang akan diterapkan di kelas $X$ untuk materi peradaban Yunani dan Romawi, 
sedangkan kelas XI akan menggunakan metode sosiodrama dengan materi peristiwa-peristiwa sekitar Proklamasi. Penjelasan guru sejarah memberikan alasan yang kuat terhadap pemilihan metode pembelajaran.

Perbedaan dua metode pada kelas yang berbeda dilakukan karena karakteristik materi pelajaran yang berbeda pula. Kelas $X$ masih harus dibimbing bagaimana cara berdiskusi, karakteristiknya masih seperti anakn SMP, sedangkan kelas XI IPS menggunakan metode sosiodrama dengan harapan siswa bisa mendalami dan menjiwa peran tokoh yang diperankan mereka. Sehingga kelas XI benar-benar mampu menjelaskan alur cerita persitiwa sekitar proklamasi yang heroik itu (wawancara dengan guru Sejarah SMAN 1 Metro, Sabtu 6 Mei 2017)

\section{Iklim Kelas}

Pertama kali memasuki ruangan kelas sejarah suasana kelas dalam pembelajaran sejarah di SMAN 1 Metro cukup terkendali. Sepertinya siswa dan guru sejarah memang sudah terbiasa melakukan proses pembelajaran dengan banyak oarang yang mengamati. Metode diskusi kelompok saat proses pembelajaran berlangsung, memberikan suasana demokratis dalam pembelajaran sejarah. Hal itu dapat terlihat dari aktivitas dan kreativitas siswa dalam pembelajaran sejarah yang dimana saat proses pembelajaran berlangsung antusias. Siswa-siswinya cukup kritis, rasa ingin tahu mereka terhadap materi pelajaran sangat besar.

Terjadi komunikasi dua arah antara peserta didik dan guru, hal ini menandakan terjalinnya hubungan baik antara guru dan peserta didik. Selain itu, hubungan antara sesama peserta didik juga terlihat baik. Guru tidak terlalu mendominasi baik dalam hal menelusuri materi, ataupun aktifitas peserta didik. Menurut pemaparan guru pengampu, beliau memang sengaja menggunakan metode 'santai' dalam mengajar. Oleh karena itu, peserta didik juga tidak terlihat tertekan.

Pada kelas XI, Guru menerapkan metode sosiodrama, dimana peserta didik dipersilahkan oleh guru untuk menentukan peran tokoh yang diinginkan, yang kemudian mereka musyawarahkan bersama satu kelas. Guru model memfasilitasi dengan baik, menyediakan laptop, serta menyiapkan contoh skenario. Serta menjelaskan terlebih dahulu materi dan menanggapi pertanyaan peserta didik.

\section{Proses pembelajaran}

Pelaksanaan pembelajaran sejarah dilakukan di SMA N 1 Metro pada hari Senin, 8 Mei 2017. Pada kesempatan ini pembelajaran sejarah dilakukan di kelas $X$ dengan mata pelajaran sejarah peminatan dan kelas XI dengan sejarah 
wajib sesuai dengan yang telah direncanakan sebelumnya.

Guru model mempresentasikan tujuan pembelajaran materi Peradaban Yunani dan Peradaban Romawi di kelas X. Kemudian mempersilahkan siswa untuk berdiskuis dengan temannya. Disini terlihat peserta didik cukup antusias. Banyaknya siswa yang bertanya kepada kelompok yang presentasi membuat pembelajaran cukup ramai dan menarik. Pertanyaan yang diberikanpun sudah kritis dan menjurus ke materi. Kemudian disini Guru memperbolehkan siswa yang presentasi untuk menggunakan smartphone untuk mengakses informasi dari internet, hal ini menunjukan pula bahwa pembelajaran disesuaikan dengan perkembangan IPTEK.

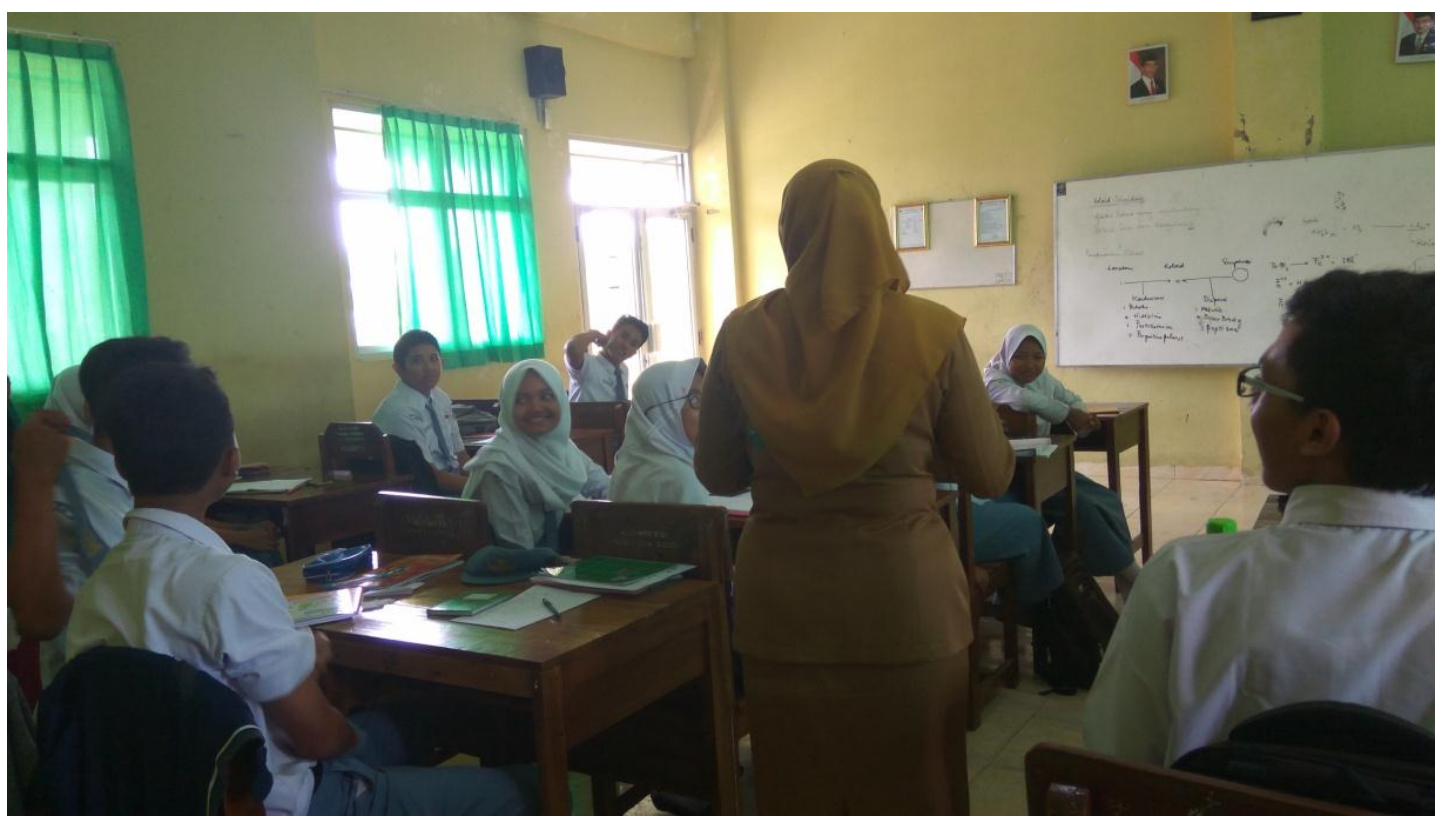

Gambar 1. Guru model memberikan arahan kepada siswa untuk berdiskusi

Sebagian besar siswa kelas $\mathrm{X}$ terlihat mengikuti pembelajaran, meskipun ada beberapa siswa yang kurang berminat (pasif). Siswa yang pasif justeru membuka media sosial. Perilaku itu luput dari perhatian guru (Hasil Observasi, 8 Mei 2017). Namun jika dilihat dari perencanaan pembelajaran sesuai dengan yang telah disepakati.

Sementara di kelas XI guru menggunakan sosiodrama pada materi
Peristiwa-peristiwa sekitar Proklamasi. Guru memilih metode ini dikarenakan siswa kelas XI IPA 1 ini banyak yang pandai dalam mengelola IT dan bermain drama. Disini peserta didik juga terlihat sangat antusias, meskipun ada beberapa peserta didik yang kurang antusias tetapi mereka tetap mengikuti jalannya pembelajaran dengan baik. Beberapa hal tersebut menunjukan bahwa guru sudah menggunakan berbagai macam metode pembelajaran. Artinya, dalam 
pembelajaran sejarah tidak terlalu sulit untuk menerapkan berbagai macam metode, tidak hanya ceramah dan mencatat. Pembelajaran sejarah dengan sosiodrama menunjukan bahwa pembelajaran sejarah juga bisa sangat menyenangkan, tidak seperti paradigma yang beredar bahwa pembelajaran sejarah itu membosankan.

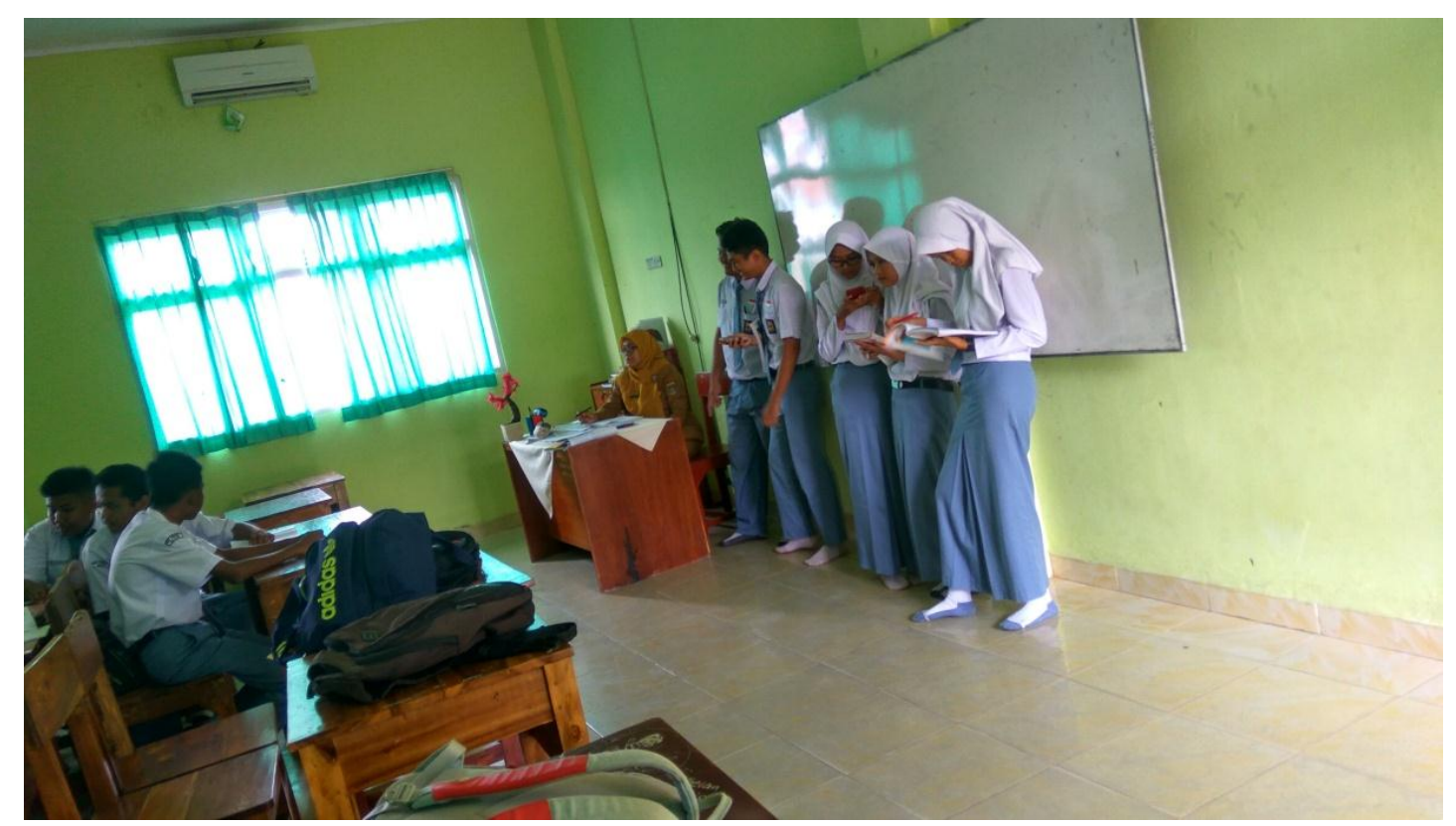

Gambar 2. Siswa sedang mepresentasikan hasil diskusinya.

\section{Persepsi Siswa Terhadap Pembelajaran}

\section{Sejarah}

Bagian ini melihat pandangan siswa mengenai pelaksanaan pembelajaran sejarah. Berdasarkan analisis dari angket yang telah disebarkan kepada 60 siswa sebagai responden, persepsi siswa terhadap pelaksanaan pembelajaran sejarah di SMAN 1 Metro mendapatkan kategori sangat baik dan berkategori baik. Kemampuan guru model membuka pelajaran dengan skor 0.85 (sangat baik), penyampaian materi pelajaran sejarah oleh guru model 0.85 (sangat baik). Dalam hal pemahaman karakteristik siswa guru model mendapatkan nilai 0.84 (sangat baik), pengelolaan pembelajaran 0.79 (baik), penguasaan strategi pembelajaran 0.69 (baik), evaluasi pembelajaran 0.62 (baik), dan penanaman karakter 0.75 (baik). 


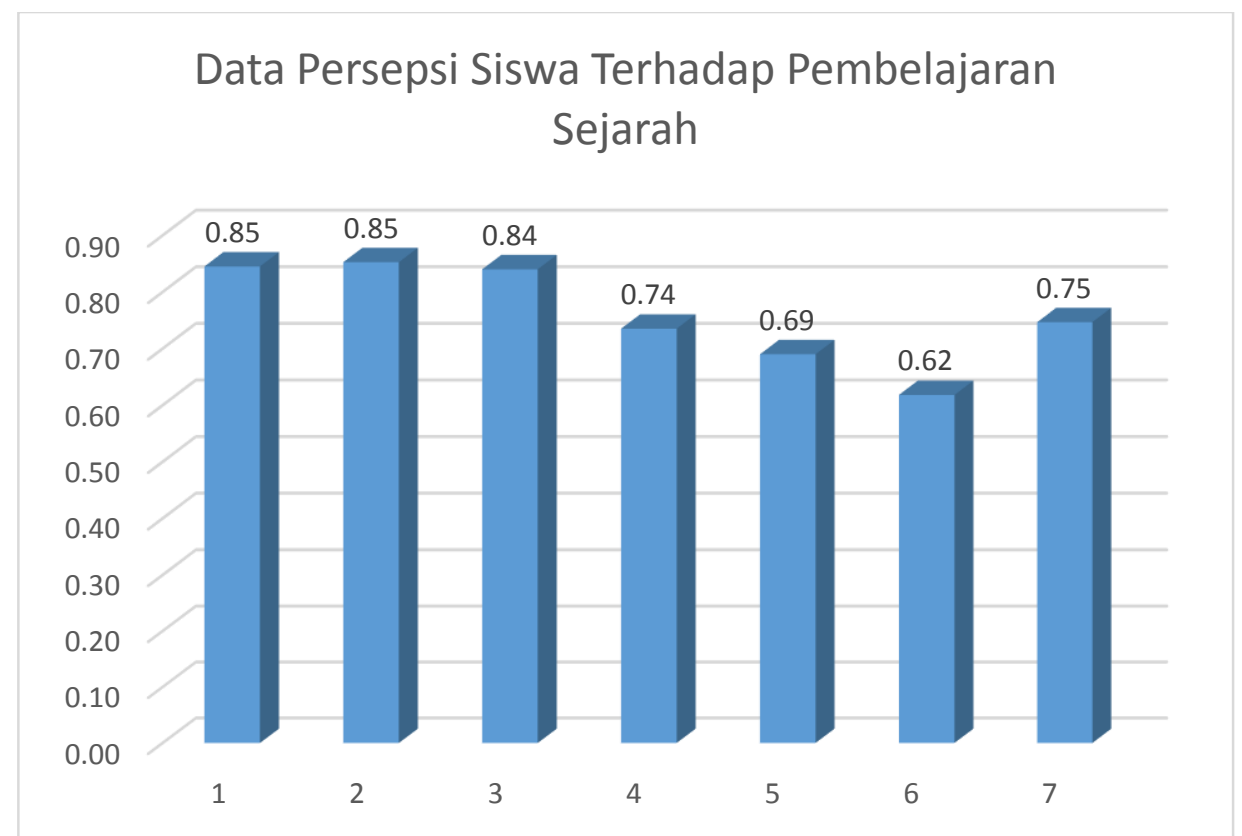

Keterangan: 1. membuka pembalajaran; (2) penguasaan materi pembelajaran; (3) pemahaman guru model terhadap karakteristik siswa; (4) pengelolaan kelas; (5) penerapan strategi dan metode dalam pembelajaran; (6) sistem penilaian (evaluasi); (7) penanaman Karakter.

\section{Beberapa Temuan dalam Penelitian}

Temuan ini adalah bagian dari refleksi yang dilakukan setelah proses pembelajaran berlangsung. Temuan tersebut antara lain:

1. Guru masih memperlakukan sama antara siswa yang memiliki perbedaan kemampuan dalam bidang sejarah. Sehingga terdapat siswa yang kurang terlayani dalam proses pembelajaran tersebut. Siswa yang memiliki kemampuan lebih (cerdas) cenderung mendominasi di kelas. Namun bagi siswa yang memiliki kemampuan kurang dalam pelajaran sejarah mereka sering terdiam dan cenderung pasif. Guru perlu mencoba untuk menerapkan sistem evaluasi yang berbeda terhadap kelas yang kemampuan siswanya heterogen.

2. Dari sisi materi pembelajaran sejarah lebih mengandalkan ingatan. Tidak jarang bahwa siswa beranggapan bahwa sejarah sebagai ilmu hafalan sesuai dengan urutan waktu secara kronologis. Namun terdapat hal yang terlupakan bahwa sejarah juga memiliki makna bagi kehidupan. Dari hasil beberapa kali observasi dan wawancara nilai-nilai karakter yang ada dalam materi sejarah belum tersampaikan, alasan yang selalu muncul adalah materi pelajaran sejarah banyak sehingga guru kesulitan untuk mengatur penyampaian materi kepada siswa. Dilaksanakannya Lesson Study membantu guru sejarah dalam 
merencanakan, mengamati dan mengevaluasi pembelajaran.

3. Waktu pembelajaran mempengaruhi terhadap konsentrasi siswa. Keluhan yang selama ini terdengar lebih pada persoalan teknis, yakni jumlah waktu pelajaran yang diberikan untuk mata pelajaran sejarah tidak sama antara satu jurusan dengan jurusan lain, sementara materi yang harus diselesaikan tidak berbeda jauh.

4. Diketahuinya kesalahan persepsi mengenai tokoh sejarah masa kemerdekaan. Siswa menganggap bahwa Sukarni adalah seorang perempuan padahal Sukarni adalah seorang laki-laki.

5. Suasana hati memiliki pengaruh besar terhadap siswa dalam menyerap materi pelajaran. Terlihat dari dua metode pembelajaran yang dilakukan guru model metode sosiodrama memiliki kesan tersendiri pada diri siswa.

6. Perlu adanya penyegaran (ice breaking) disela-sela proses pembelajaran sejarah untuk memulihkan kembali konsentrasi siswa.

7. Dalam pelaksanaan refleksi diungkapkan juga mengenai beberapa siswa yang membuka media sosial dan luput dari teguran guru. Guru sejarah mengakui kekurang itu, dan berargumen bahwa "Beberapa siswa yang pasif dalam pembelajaran disebabkan karena siswa yang memiliki karakter berbeda-beda, jadwal pelajaran siang hari sehingga siswa kurang kondusif".

\section{PENUTUP}

\section{Kesimpulan}

Secara umum Pelaksanaan pembelajaran sejarah berbasis lesson study berjalan dengan lancar, namun perlu ada pengkajian secara lebih mendalam mengenai komunitas lesson study antar guru sejarah. Hal itu dapat difasilitasi oleh MGMP sejarah. Guru sejarah perlu mendalami mengenai jumping task agar siswa yang memiliki kemampuan diatas rata-rata menjadi lebih terfasilitasi dalam proses pembelajaran.

\section{Ucapan Terimakasih}

Peneliti mengucapkan terimakasih kepada pihak-pihak yang telah membantu berjalannya penelitian ini terkhusus kepada Kepala Sekolah SMAN 1 Metro, guru sejarah SMAN 1 Metro Ibu Suti Suryani, S.Pd dan Mahasiswa Pendidikan Sejarah yang telah meluangkan waktu, menemani dan mengambil data di lapangan.

\section{REFERENSI}

Baum, E., Brown, K., Minter, B., \& Smoak, T. (2015). Engageing In Lesson Study. http://kb.gcsu.edu/src/2015/frida $\mathrm{y} / 51 /$ ) 
Dudley, P. (2014). Lesson Study: a handbook. (disde.minedu.gob.pe) diakses pada 14 Juni 2017.

Hasan, S. H. (2012). Pendidikan Sejarah untuk Memperkuat Pendidikan Karakter. Paramita: Historical Studies Journal, 22(1).

Kuswono, K. (2015). Kinerja Guru Sejarah SMA Di Kota Metro. HISTORIA, 3(2), 91-98.

Lewis, C. (2000). Lesson Study: The Core of Japanese Professional Development.)

Lewis, C., Perry, R., \& Murata, A. (2006). How should research contribute to instructional improvement? The case of lesson study. Educational researcher, 35(3), 3-14.)

Mahmudi, A. (2009). Mengembangkan Kompetensi Guru Melalui Lesson Study. In Jurnal Forum Kependidikan FKIP UNSRI (Vol. 28)

Subakti, Y. R. (2010). Paradigma Pembelajaran Sejarah Berbasis Konstruktivisme. Jurnal SPPS, 24(1).

Susilo, H. (2013). Lesson Study sebagai sarana meningkatkan kompetensi Pendidik. In Makalah) disajikan dalam Seminar dan Lokakarya PLEASE (pp. 28-34)

Wawancara dengan Suti Suryani pada Senin 8 mei 2017 di SMA N 1 Metro.

Winarsih, A., \& Mulyani, S. (2012). Peningkatan Profesionalisme Guru IPA melalui Lesson study Dalam Pengembangan Model Pembelajaran PBI. Jurnal Pendidikan IPA Indonesia, 1(1). 
Pelaksanaan Pembelajaran Sejarah Berbasis Lesson Study, Kuswono, 163- 